intestinal local immunity may have provided enough protection to prevent diarrhoea.

It has been suggested that there are subtypes of this virus, which might explain the variety of clinical courses. $^{8}$ We ourselves have suggested that immunological responses of this illness might differ from those in most other common viral infections, with individual differences in the acquisition of local immunity within the intestine. ${ }^{9}$

\footnotetext{
References

1 Walker-Smith J A. Rotavirus gastroenteritis. Arch Dis Child 1978; 53: 355-62.

2 Konno T, Suzuki H, Ishida N. Letter: Reovirus-like agent in Japanese infants with gastroenteritis. Lancet 1975; 1 : 918-9.

3 Sakamoto A, Iijima S, Suzuki S, Shirasawa S, Mori Y, Niimi M. Clinical and pathological studies on Hakuri, infantile diarrhoea with milky white stool. Ann Paediatrici 1964; 202: 293-302.
}

4 Morishima T, Ichikawa T, Yamaguchi H, et al. Acute infantile gastroenteritis caused by rotavirus in Japan. Eur J Pediatr 1978; 129: 259-65.

5 Bishop R F, Davidson G P, Holmes I H, Ruck B J. Detection of a new virus by electron microscopy of faecal extracts from children with acute gastroenteritis. Lancet $1974 ; 1$ : 149-50.

- Matsuno M, Nagayoshi S. Quantitative estimation of infantile gastroenteritis virus antigens in stools by immune adherence hemagglutination test. J Clin Microbiol 1978; 7: 310-1.

7 Murphy A M, Albrey M B, Crewe E B. Rotavirus infections of neonates. Lancet 1977; 2 : 1149-50.

8 Fonteyne J, Zissis G, Lambert J P. Letter: Recurrent rotavirus gastroenteritis. Lancet 1978; 1 : 983.

- Morishima T, Nagayoshi S, Ozaki T, Isomura S, Suzuki S. Letter: Immunofluorescence of human reovirus-like agent of infantile diarrhoea. Lancet 1976; 2: 695-6.

Correspondence to $\operatorname{Dr} T$ Morishima, Department of Paediatrics, Nagoya University School of Medicine, 65 Tsuruma-Cho, Showa-Ku, Nagoya, Japan.

\title{
Primary vesicoureteric reflux in neonates with imperforate anus
}

\section{A M K RICKWOOD AND L SPITZ}

\author{
The Children's Hospital, Western Bank, Sheffield
}

SUMMARY Cystography, performed in 26 out of a total of 33 consecutive neonates with imperforate anus, revealed primary vesicoureteric reflux in 12 cases. The reflux was usually pronounced, and was particularly common in females and in infants with urinary tract infections. The incidence of reflux was unrelated to the severity of the anorectal anomaly, and reflux was often demonstrated in patients in whom an intravenous pyelogram had shown an undilated upper renal tract.

Primary vesicoureteric reflux (VUR) is the most common anomaly of the upper renal tract in childhood $^{1}$ and it was expected that this condition might often be found in infants with an imperforate anus, in whom the incidence of upper renal tract anomalies is such that a neonatal intravenous pyelogram (IVP) is generally considered mandatory. In four major series in which the genitourinary tract anomalies associated with imperforate anus were described, Singh et al. ${ }^{2}$ and Hasse $^{3}$ mentioned VUR but gave no statistics, while Wiener and Kiesewetter ${ }^{4}$ listed only 11 examples in a series of 200 cases. Smith ${ }^{5}$ was the only one to advocate a micturating cystourethrogram (MCU) as a routine in neonates with imperforate anus; he found 13 examples of VUR in
195 cases. At this hospital it was not formerly the practice to perform an MCU routinely in patients with imperforate anus, but when we did perform one in response to a particular indication (unexplained urinary tract infection, upper tract dilatation on IVP, to demonstrate a rectourethral fistula, etc.), VUR was often revealed, and reimplantation of refluxing ureters was virtually the only urological surgery undertaken in these patients. As a result, it is now our practice to perform an MCU in any new case of imperforate anus.

\section{Case material and findings}

33 new patients with imperforate anus presented as neonates in the 3-year period January 1976 to December 1978. Three died before their renal tracts had been investigated, and 4 had IVPs only. The remaining 26 had both IVPs and MCUs before being discharged from hospital. The radiological findings in these cases are shown in Table 1, and the comparison between the MCU and clinical findings in Table 2. Generally VUR of grades I and II only took place during voiding, and grade $\mathrm{III}$ during both filling and emptying of the bladder. Only one patient had a sacral deficiency likely to produce neurogenic bladder dysfunction; his MCU showed no reflux. It is too 
early to assess the progress of the VUR or its effects on the kidneys, but 3 patients with grade III reflux showed early renal scarring when reinvestigated between 1 and 2 years of age. All 3 had had urinary tract infections which had apparently been adequately controlled with antibiotics: 2 have undergone reimplantation of their refluxing ureters.

Table 1 Radiological findings (IVP and MCU) in 26 patients with imperforate anus

\begin{tabular}{|c|c|c|c|c|}
\hline $\begin{array}{l}\text { MCU findings } \\
\text { VUR unilateral } \\
\text { VUR bilateral } \\
\text { Total }\end{array}$ & \multicolumn{2}{|c|}{$\begin{aligned} 8 & \text { (3 with solitary kidney) } \\
4 & \\
16 & \text { refluxing pyelons } \\
2 & \text { grade } \mathrm{I}^{*} \\
3 & \text { grade } \mathrm{II}^{*} \\
11 & \text { grade } \mathrm{III}^{*}\end{aligned}$} & & \\
\hline \multicolumn{3}{|c|}{$\begin{array}{l}\text { Comparison between IVP and } M C U \text { findings } \\
\text { IVP } \\
\text { Normal bilateral }\end{array}$} & $\begin{array}{l}M C U \\
\text { VUR } \\
\text { No VUR }\end{array}$ & $\begin{array}{r}9 \\
10\end{array}$ \\
\hline \multicolumn{2}{|c|}{ Normal solitary functioning kidney } & 2 & $\begin{array}{l}\text { VUR } \\
\text { No VUR }\end{array}$ & $\stackrel{2}{-}$ \\
\hline \multicolumn{2}{|c|}{$\begin{array}{l}\text { Solitary functioning kidney with ureteric } \\
\text { dilatation }\end{array}$} & 3 & $\begin{array}{l}\text { VUR } \\
\text { No VUR }\end{array}$ & $\begin{array}{l}1 \\
2\end{array}$ \\
\hline \multicolumn{2}{|c|}{ Unilateral pelviureteric obstruction } & 1 & $\begin{array}{l}\text { VUR } \\
\text { No VUR }\end{array}$ & $\overline{1}$ \\
\hline \multicolumn{2}{|l|}{ Horseshoe kidney } & 1 & $\begin{array}{l}\text { VUR } \\
\text { No VUR }\end{array}$ & $\overline{1}$ \\
\hline
\end{tabular}

* Grade I reflux into ureter only, grade II complete reflux without dilatation, grade III complete reflux with dilatation of pelvicalyceal system.

Table 2 Correlation between $M C U$ and clinical findings

\begin{tabular}{lllll}
\hline & & $\begin{array}{l}\text { Male } \\
n=17(5)\end{array}$ & $\begin{array}{l}\text { Female } \\
n=9(7)\end{array}$ & $\begin{array}{l}\text { Total } \\
n=26(12)\end{array}$ \\
\hline $\begin{array}{l}\text { Urinary tract } \\
\text { infection* }\end{array}$ & $\begin{array}{l}\text { None } \\
\text { Present }\end{array}$ & $\begin{array}{c}12(1) \\
5(4)\end{array}$ & $\begin{array}{l}2(2) \\
7(5)\end{array}$ & $14(3)$ \\
Anorectal anomaly & High & $8(2)$ & $4(2)$ & $12(4)$ \\
& Low & $9(3)$ & $5(5)$ & $14(8)$ \\
Birthweight & $>3 \mathrm{~kg}$ & $11(3)$ & $4(4)$ & $15(7)$ \\
& $<3 \mathrm{~kg}$ & $6(2)$ & $5(3)$ & $11(5)$ \\
Major associated & None & $12(3)$ & $8(6)$ & $20(9)$ \\
anomaly $\dagger$ & Present & $5(2)$ & $1(1)$ & $6(3)$ \\
\hline
\end{tabular}

Figures in brackets indicate numbers with vesicoureteric reflux.

* Excludes urinary tract infections occurring in the presence of a rectourethral fistula, +3 tracheo-oesophageal fistula and oesophageal atresia, 1 duodenal atresia, 1 colonic atresia, 1 oesophageal atresia, duodenal atresia, malrotation and subglottic stenosis.

\section{Discussion}

On the basis of this fairly small series, the following features emerge: (1) primary VUR is a common abnormality of the upper renal tract in patients with imperforate anus, occurring in $12(45 \%)$ of the 26 cases fully investigated; (2) when present, VUR tends to be quite severe (grade III); (3) the demon- stration of normal upper tracts without ureteric dilatation on IVP does not exclude the presence of VUR of any degree; (4) VUR is more common in females; (5) although VUR is more likely to be present when there is a urinary tract infection which cannot be explained by the presence of a rectourethral fistula, the absence of such infection does not exclude the presence of reflux; (6) there is no correlation between the incidence of VUR and the type of anorectal anomaly, the birthweight, or the presence or absence of other associated major congenital abnormalities.

Whether routine screening of these cases for VUR is justified depends not only on the incidence of reflux, but whether this is likely to be a cause of long-term renal damage. It is generally accepted that renal scarring rarely occurs except in the presence of more severe (grade III) VUR. ${ }^{6}$ It has also been stated that VUR in the absence of urinary tract infection does not cause renal damage. ${ }^{7}$ Whatever the mechanism of reflux pyelonephritis, there is evidence that the damage usually occurs in the first few years of life. ${ }^{8}$

From these findings, we recommend an MCU be done in addition to an IVP in all neonates with anorectal anomalies. Even if this policy is not adopted, the demonstration of 2 normal kidneys on a neonatal IVP should not induce a false sense of security about the continued normality of the upper renal tracts, and, at the very least, these patients should be closely monitored for urinary tract infections in their early years and an MCU performed, should one be found.

\section{References}

1 Smellie J M, Normand I C S. Clinical features and significance of urinary tract infection in children. Proc $R$ Soc Med 1966; 59: 415-6.

2 Singh M P, Haddadin A, Zachary R B, Pilling D W. Renal tract disease in imperforate anus. $J$ Pediatr Surg 1974; 9: 197-202.

3 Hasse W. Associated malformations with anal and rectal atresias. Prog Pediatr Surg 1976; 9: 99-103.

4 Wiener E S, Kiesewetter W B. Urologic abnormalities associated with imperforate anus. J Pediatr Surg 1973; 8: 151-7.

5 Smith E D. Urinary anomalies and complications in imperforate anus and rectum. $J$ Pediatr Surg 1968; 3: 337-9.

6 Edwards D, Normand I C S, Prescod N, Smellie J M. Disappearance of vasicoureteric reflux during long-term antibiotic prophylaxis of urinary tract infection in children. Br Med J 1977; ii : 285-8.

7 Editorial: Screening for reflux. Lancet 1978; 2 : 23-4.

${ }^{8}$ Scott J E S, Stansfeld J M. Ureteric reflux and scarring in children. Arch Dis Child 1968; 43: 468-70.

Correspondence to A M K Rickwood FRCS, Paediatric Surgical Unit, Children's Hospital, Western Bank, Sheffield S10 2TH. 